\title{
Influence of Bed Movement and Amount of Supplied Air on Updraft Gasification of Hardwood Pellet
}

\section{Utjecaj pomaka tepiha materijala i dobave zraka na protusmjerno rasplinjavanje peleta od drva listača}

Original scientific paper • Izvorni znanstveni rad

Received-prispjelo: 16. 11. 2017.

Accepted-prihvaćeno: 27. 11. 2018.

UDK: $630 * 812.585$

doi:10.5552/drind.2018.1764

\begin{abstract}
This work presents the results of hardwood pellet gasification with different amounts of air as a gasification medium. The effects of bed movement and the equivalence ratio (ER) on the temperature profile, gas composition, carbon conversion efficiency and the energy balance were taken into account. Slow movement of the bed promotes high combustion and reduction zones, while fast bed movement leads to high pyrolysis zones and higher caloric values of syngas. When the amount of air increased from 12 to $23 \mathrm{Nm}^{3} / \mathrm{h}$, the gas yield increased from 1.4 to $1.6 \mathrm{Nm}^{3} / \mathrm{kg}_{\text {biomass }}$ for slow bed movement, and from 1.0 to $1.3 \mathrm{Nm}^{3} / \mathrm{kg}_{\text {biomass }}$ for fast bed movement. These results show that in both Cases similar specific energy values were obtained. However, in Case 1 lower fuel consumption was reached. Chemical energy in the syngas represents $80 \%$ of the output energy for slow bed movement $(265 \mathrm{MJ} / \mathrm{h})$ and $75 \%$ for fast bed movement $(295 \mathrm{MJ} / \mathrm{h})$. A significant effect of bed movement in the reactor suggests that the gasifier could be considered as a flow reactor, and additionally the fast movement of the bed with 20 $\mathrm{Nm}^{3} / \mathrm{h}$ of supplied air yielded the highest-quality gasification process. Moreover, fast bed movement in the reactor leads to a high amount of generated char with high energy potential.
\end{abstract}

Keywords: gasification, updraft gasifier, hardwood, carbon conversion, bed movement

SAŽETAK • U radu su prikazani rezultati rasplinjavanja peleta od drva listača različitim količinama zraka kao sredstvom za rasplinjavanje. U ispitivanju je uzet u obzir utjecaj pomaka tepiha materijala i omjera ekvivalencije (ER) na temperaturni profil, sastav plina i učinkovitost pretvorbe ugljika te na energetsku ravnotežu. Usporeni pomak tepiha materijala pospješuje zone dobrog izgaranja i redukcije, dok brzi pomak tepiha materijala rezultira visokim zonama pirolize $i$ višim kalorijskim vrijednostima sintetskog plina. Kada je količina zraka porasla s 12 na

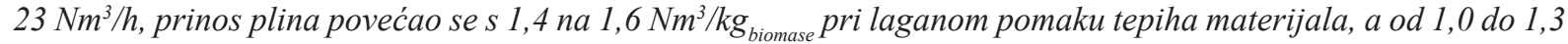
$\mathrm{Nm}^{3} / \mathrm{kg}_{\text {biomase }}$ pri brzom pomaku tepiha materijala. Ti rezultati pokazuju da su u oba primjera dobivene slične vrijednosti specifične energije. Međutim, u prvom je primjeru postignuta niža potrošnja goriva. Kemijska energija u sintetskom plinu čini $80 \%$ izlazne energije pri laganom pomaku tepiha materijala $(265 \mathrm{MJ} / \mathrm{h})$ i $75 \%$ pri brzom pomaku tepiha materijala (295 MJ/h). Znatan učinak pomaka tepiha materijala u reaktoru sugerira da se rasplinjač

\footnotetext{
${ }^{1}$ Authors are researcher at Institute of Fluid-Flow Machinery, Polish Academy of Sciences, Gdańsk, Poland. ${ }^{2}$ Author is PhD student at Gdańsk Univeristy of Technology, Faculty of Mechanical Engineering Gdańsk, Poland.

Autori su istraživači Odsjeka za hidrauličke strojeve, Poljska akademija znanosti, Gdanjsk, Poljska. ${ }^{2}$ Autor je doktorand Tehnološkog sveučilišta u Gdanjsku, Strojarski fakultet, Gdanjsk, Poljska.
} 
može smatrati protočnim reaktorom, a dodatno brz pomak tepiha materijala s $20 \mathrm{Nm}^{3} / \mathrm{h}$ dobave zraka omogućio je najkvalitetniji proces rasplinjavanja. Štoviše, brzi pomak tepiha materijala u reaktoru dovodi do nastanka velike količine pougljenjenog materijala s visokim energetskim potencijalom.

Ključne riječi: rasplinjavanje, protusmjerni rasplinjač, drvo listača, pretvorba ugljika, pomak tepiha materijala

\section{INTRODUCTION}

1. UVOD

The gasification process, which is recognized as one of the most effective in terms of thermal utilization of biomass and municipal waste, is a very popular topic in global research (Arena, 2012). This process is typically classified based on the type of gasification system. A common construction is a fixed-bed gasifier working in the downdraft or updraft configuration (McKendry, 2002). Downdraft gasification systems generate gas with a lower tar content than updraft gasifiers. Therefore, many studies focused on different types of downdraft gasifiers can be found in the literature (Balu and Chung, 2012; Phuphuakrat et al., 2010; Nisamaneenate et al., 2012; Zainal et al., 2002; Erlich et al., 2011). In the case of updraft reactors, the high tar content in the produced gas has significantly slowed the development of this technology (Dudyński et al., 2012). However, studies based on updraft gasification are described in the literature. Blasi et al. (1999) used beechwood biomass in an updraft fixed-bed gasification process, which resulted in gas with a content of 28 $\% \mathrm{CO}, 7 \% \mathrm{CO}_{2}, 7 \% \mathrm{H}_{2}$ and $2 \% \mathrm{CH}_{4}$.

Chen et al. (2011) studied the operating conditions of updraft gasification of mesquite and juniper and found that the heating value of syngas increased from 3.5 to $3.9 \mathrm{MJ} / \mathrm{Nm}^{3}$ for juniper and from 2.4 to 3.5 $\mathrm{MJ} / \mathrm{Nm}^{3}$ for mesquite when the equivalence ratio (ER) decreased from 0.37 to 0.22 . For both types of fuel, the maximum temperature in the combustion zone was above $1000^{\circ} \mathrm{C}$.

Pedroso et al. (2013) studied wood chip gasification in bottom-feed updraft gasification and showed that the gas produced contained $27 \% \mathrm{CO}$ and $4 \% \mathrm{CH}_{4}$ and, relative to a typical updraft gasification system, a lower concentration of $\mathrm{H}_{2}(6 \%)$. The temperature of the bed in the reactor decreased from $885^{\circ} \mathrm{C}$ in the combustion zone to $100^{\circ} \mathrm{C}$ in the drying zone.

Recent research has focused on methods to clean the producer gas, optimize the updraft gasification process to decrease the high content of tar in the syngas, and obtain high-quality biochar (Taupe et al., 2016). Ismail and El-Sala (2017) carried out numerical simulations and experimental studies of the influence of temperature in the gasifier and ER on syngas composition and tar yields during updraft gasification of wood pellets. It was reported than the ER had a significant impact on bed temperature and gas quality. A higher ER ratio corresponds to a larger amount of oxygen in the combustion zone, which leads to a lower concentration of carbon monoxide and hydrogen and also increases the carbon dioxide content of the syngas. On the other hand, more oxygen supplied to the gasifier promotes oxidization reactions and leads to more heat generation and higher temperatures in the gasifier. These aspects were also presented by Ayyadurai et al. (2017), who studied large (1 $\mathrm{m}$ in length and $0.06 \mathrm{~m}$ in diameter) woody biomass gasification in a $60 \mathrm{~kW}_{\text {th }}$ updraft gasifier. These authors found that the gasification process with $\mathrm{ER}=0.6$ producer syngas attained a heating value of $4.5 \mathrm{MJ} / \mathrm{Nm}^{3}$ and that the gasification temperature reached a temperature of $955^{\circ} \mathrm{C}$ in the oxidation zone.

Another interesting issue related to updraft biomass gasification has been presented by Huang et al. (2017). These authors studied the characteristics of residual carbon in biomass, including structure and gasification activity. These aspects were investigated using Raman spectroscopy. Residual carbon in the ash is the result of char particles spending only a short amount of time in the gasifier.

Based on current literature, there are no available works that provide detailed information about the influence of time that the fuel spends in the gasifier or rate of bed movement and the amount of supplied air on the gasification temperature and syngas characteristics. The primary objective of this work was to investigate an alternative way to stimulate the updraft gasification process by forcing different rates of bed movement at different amounts of supplied air. The main parameters presented in this work include the temperature profile along the gasifier (e.g., the characteristics of the temperature zones, gas composition and caloric value, carbon conversion rate and energy balance).

\section{MATERIALS AND METHODS \\ 2. MATERIJALI I METODE}

\subsection{Proximate and ultimate analysis of fuel}

2.1. Neposredna i krajnja analiza goriva

The hardwood pellets particles are a cylinder with diameter of $8 \mathrm{~mm}$ and length of up to $15 \mathrm{~mm}$. The bulk density of hardwood pellets during experiments was $646 \mathrm{~kg} / \mathrm{m}^{3}$. To conduct the proximate and ultimate analyses, the hardwood samples were first dried using a moisture analyzer (RADWAG) to determine their moisture content. The analysis of elementary composition was carried out using a CHNS-O Flash 2000 analyzer. The determination and calculation of the calorific value was executed using a KL-11 calorimeter. The results of the proximate and ultimate analyses are presented in Table 1.

\subsection{Gasification stand}

\subsection{Postrojenje za rasplinjavanje}

The experimental setup for the updraft gasification is shown in Figure 1. The gasifier was constructed using boiler steel and clad on mineral wool isolation. The total height of the reactor was $135 \mathrm{~cm}$ and its internal radius was $22 \mathrm{~cm}$. The air inlet (three axially spaced 


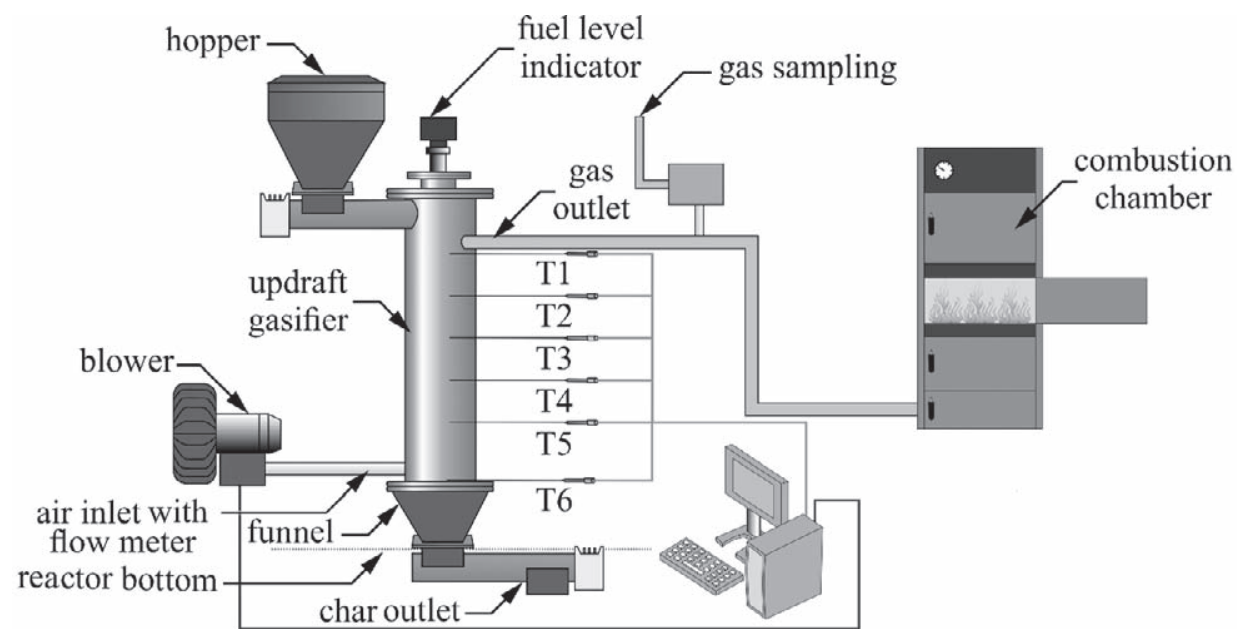

Figure 1 Schematic diagram of the experimental setup

Slika 1. Shematski prikaz istraživačkog postrojenja

Table 1 Duncan's test results for main effects Tablica 1. Rezultati Duncanova testa za glavne utjecajne činitelje

\begin{tabular}{|c|c|}
\hline & $\begin{array}{l}\text { Hardwood pellets } \\
\text { Peleti od drva listača }\end{array}$ \\
\hline $\mathrm{HHV}, \mathrm{MJ} / \mathrm{kg}$ & 19.6 \\
\hline Moisture, wt.\%. as delivered & 6.1 \\
\hline \multicolumn{2}{|l|}{$\begin{array}{l}\text { Proximate, wt. } \%_{\mathbf{d b}}{ }^{\mathbf{a}} \\
\text { Neposredno, wt. }{ }_{d b}^{a}\end{array}$} \\
\hline Volatiles / hlapljive komponente & 76.3 \\
\hline Fixed Carbon / fiksni ugljik & 21.4 \\
\hline Ash / pepeo & 2.3 \\
\hline \multicolumn{2}{|l|}{$\begin{array}{l}\text { Ultimate, wt. } \%_{\mathbf{a b}}{ }^{\mathbf{a}} \\
\text { Krajnje, wt. } \%_{d b}{ }^{a}\end{array}$} \\
\hline $\mathrm{C}$ & 48.5 \\
\hline $\mathrm{H}$ & 5.3 \\
\hline $\mathrm{O}^{\mathrm{b}}$ & 45.8 \\
\hline $\mathrm{N}$ & 0.4 \\
\hline
\end{tabular}

${ }^{\mathrm{a}} \mathrm{db}$ - oven-dry basis / na bazi standardno suhe tvari

${ }^{\mathrm{b}}$ by difference / prema razlici

nozzles with a diameter of $8 \mathrm{~mm}$ ) was installed $52 \mathrm{~cm}$ from the bottom of the reactor, ended with a funnel with $43 \mathrm{~cm}$ and it was connected with the char outlet tube with a diameter of $104 \mathrm{~mm}$. The syngas outlet was installed $111 \mathrm{~cm}$ from the bottom.

During the experimental investigation, fuel from the hopper was loaded by a screw feeder, and tube with a diameter of $104 \mathrm{~mm}$, to the reactor $10 \mathrm{~cm}$ below the syngas outlet. Six thermocouples (Type N and S) were installed in order to measure temperature within the gasifier. These thermocouples were placed 30, 55, 72, 88,90 and $119 \mathrm{~cm}$ from the bottom of the reactor. The air was supplied to the gasifier via an electric blower and controlled using an inverter and a thermal mass flow meter. The syngas left the reactor and passed to the combustion chamber, through an outlet tube with a diameter of $54 \mathrm{~mm}$. On the outlet tube, part of the produced gas was directed to the gas sampling system.

\subsection{Experimental procedure}

2.3. Postupak istraživanja

Prior to starting gasification, a batch of $3 \mathrm{~kg}$ feedstock was loaded into the gasifier in each experiment.
The initial level of the feedstock was maintained at the level of the air inlet nozzles until a high bed temperature was obtained. After a high bed temperature was obtained, the gasifier was filled to the level of the indicator. In each experiment, the height of the fuel bed was kept at the same level using a rotary fuel level indicator (i.e. $112 \mathrm{~cm}$ from the bottom). The amount of supplied air was set at 12,17, 20 and $23 \mathrm{Nm}^{3} / \mathrm{h}$, and the duration of each experiment was 120 minutes from the point when the gasification process reached a steadystate condition (i.e. a constant temperature in each zone and a steady amount of received char). The gasification process was performed at atmospheric pressure in the range of $900-1100{ }^{\circ} \mathrm{C}$. The solid residue (char and ash) was gathered from the bottom of the reactor using an inverter coupled with a cyclical screw at a frequency of $5 \mathrm{sec} / 5 \mathrm{~min}$ (Case 1) and $10 \mathrm{sec} / 2.5 \mathrm{~min}$ (Case 2), which stimulated slow and fast bed movement in the reactor (char outlet velocity)

\subsection{Measurements of gas composition 2.4. Mjerenje sastava plina}

After steady-state conditions of gasification were achieved, the samples of syngas were sampled using tedlar bags. The analysis of the syngas content was performed using a SRI Instruments 310 gas chromatograph with a ShinCarbon ST 80-100 packed column and a thermal conductivity detector. The gas analyzer was pre-calibrated using a standard mixture of gas $\left(\mathrm{CO}, \mathrm{CO}_{2}, \mathrm{CH}_{4}\right.$ and $\left.\mathrm{H}_{2}\right)$, and argon was used as a carrying medium.

\section{RESULTS AND DISCUSSION 3. REZULTATI I RASPRAVA}

\subsection{Temperature profile in the gasifier}

3.1. Temperaturni profil u rasplinjaču

Experimental investigations of hardwood pellet updraft gasification revealed a similar temperature profile trend in the gasifier, which is consistent with the literature (Chen et al., 2012; Joseph et al., 2016). The results indicated a significant impact of bed movement velocity in the gasifier on the height of individual pro- 


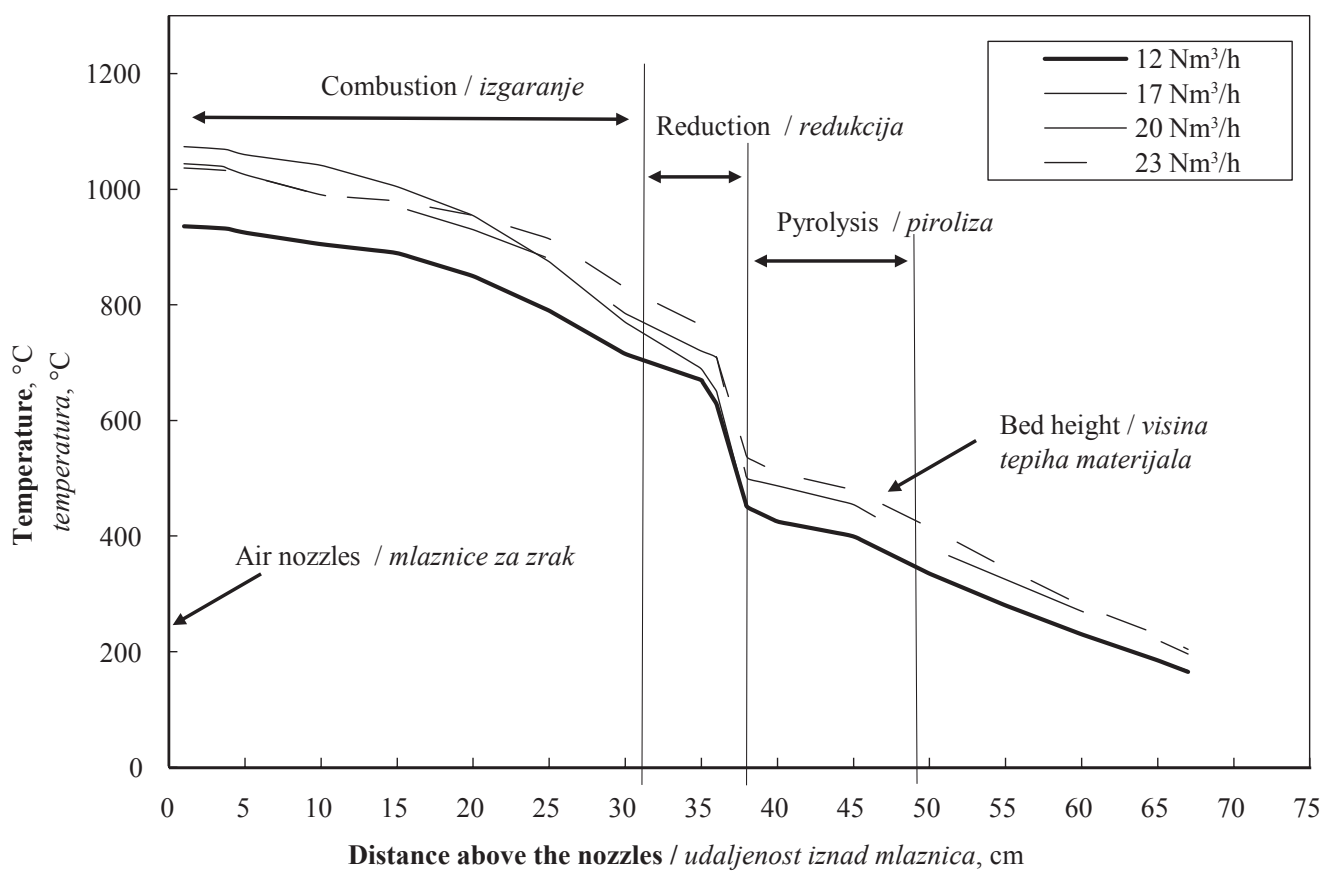

Figure 2 Characteristic temperature profile and gasifier zones in Case 1

Slika 2. Karakteristični temperaturni profil i zone rasplinjavanja u primjeru 1.

cess zones (Figure 2 and Figure 3). Based on the literature, the boundary of the combustion and reduction zone was established at $1000{ }^{\circ} \mathrm{C}$ and $750{ }^{\circ} \mathrm{C}$ (Chen et al., 2012; Sircar et al., 2014; Mani et al., 2011). Our results show that, in Case 1 (slow bed movement in the reactor), the combustion zone attained a height of about $32 \mathrm{~cm}$ from the air nozzles and the reduction zone reached a maximum height of $7 \mathrm{~cm}$.

Since the level of the fuel in the gasifier was set at $50 \mathrm{~cm}$ from the air nozzles, the pyrolysis zone attained a height of $11 \mathrm{~cm}$. In Case 2 (fast bed movement in the reactor), the height of the combustion (reduc- tion) zone attained a maximum of $16 \mathrm{~cm}$. Case 2 promoted the pyrolysis process with a zone height of 17 $\mathrm{cm}$. Lower temperatures in pyrolysis zone in Case 2 are associated with the intensification of supplied fresh fuel and consumed heat, supplied by oxidation of biomass at the lower part of the reactor, in endothermic pyrolysis reactions (high temperature gradient between 35 and $40 \mathrm{~cm}$ from the air nozzles, Figure 3 ).

The results of the hardwood updraft gasification also indicated that the gradient of the bed temperature was about $6^{\circ} \mathrm{C} / \mathrm{cm}$ for $12 \mathrm{Nm}^{3} / \mathrm{h}$ of supplied air and 10 ${ }^{\circ} \mathrm{C} / \mathrm{cm}$ for all other amounts of air in Case 1. In Case 2,

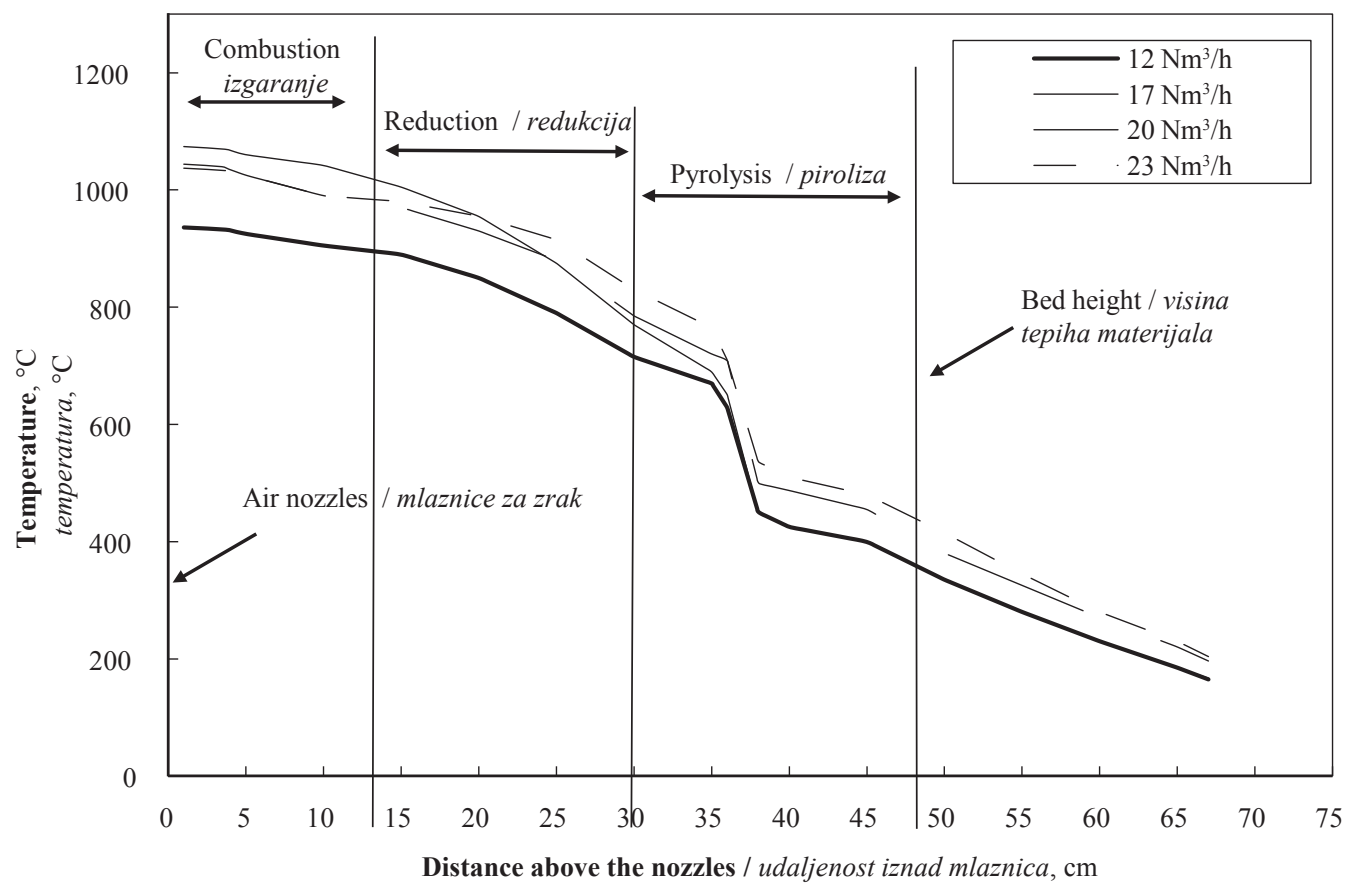

Figure 3 Characteristic temperature profile and gasifier zones in Case 2

Slika 3. Karakteristični temperaturni profil i zone rasplinjavanja u primjeru 2. 
Table 2 Performance of the gasification process

Tablica 2. Obilježja procesa rasplinjavanja

\begin{tabular}{|c|c|c|c|c|}
\hline $\begin{array}{c}\text { Case } \\
\text { Primjer }\end{array}$ & $\begin{array}{l}\text { Air, } \mathbf{N m}^{3} / \mathbf{h} \\
Z r a k, \mathrm{Nm}^{3} / \mathrm{h}\end{array}$ & $\begin{array}{c}\text { Fuel consumption, } \mathbf{k g} / \mathbf{h} \\
\text { Potrošnja goriva, } \mathrm{kg} / \mathrm{h}\end{array}$ & $\begin{array}{l}\mathbf{E R} \\
E R\end{array}$ & $\begin{array}{l}\text { Temperature, }{ }^{\circ} \mathbf{C} \\
\text { Temperatura, }{ }^{\circ} \mathrm{C}\end{array}$ \\
\hline \multirow{4}{*}{ Case 1 / primjer 1 . } & 12 & 14.6 & 0.16 & 774 \\
\hline & 17 & 19.61 & 0.16 & 1092 \\
\hline & 20 & 23.0 & 0.16 & 1094 \\
\hline & 23 & 27.0 & 0.16 & 1056 \\
\hline \multirow{4}{*}{ Case 2 / primjer 2.} & 12 & 26.2 & 0.09 & 936 \\
\hline & 17 & 27.1 & 0.12 & 1074 \\
\hline & 20 & 28.8 & 0.13 & 1044 \\
\hline & 23 & 33.7 & 0.13 & 1038 \\
\hline
\end{tabular}

the corresponding values were $12{ }^{\circ} \mathrm{C} / \mathrm{cm}$ and $13{ }^{\circ} \mathrm{C} /$ $\mathrm{cm}$. Faster bed movement in the reactor resulted in a slightly steeper temperature gradient.

\subsection{Performance of the gasification process 3.2. Obilježja procesa rasplinjavanja}

Experimental investigation showed the importance of comparing the amount of air supplied, fuel consumption, equivalence ratio and temperature. The results presented in Table 2 show similar temperature and fuel consumption trends as a function of the amount of air. However, in Case 1 the same value of ER was rated (0.16) in each experiment. In Case 2 ER value increased from 0.09 to 0.13 , which is related to similar fuel consumption with the simultaneous increase in the amount of supplied air. It is noteworthy that, in Case 2, increasing of the amount of air supplied to $23 \mathrm{Nm}^{3} / \mathrm{h}$ led to a significant increase in fuel consumption (from 28.8 to $33.7 \mathrm{~kg} / \mathrm{h}$ ), which may be caused by the increase of the intensity of oxidation/reduction processes.

\subsection{Gas calorific value}

\subsection{Ogrjevna vrijednost plina}

In an updraft gasifier, carbon dioxide is generated via the oxidation of wood pellets in the lower part of the reactor, and carbon monoxide is produced by a char reduction reaction (Boudouard reaction) in the reduction zone between the bottom and the middle parts of the reactor. Pyrolytic gas is produced in the pyrolityc zone at the lower-middle part of the gasifier (McKendry, 2002).

Different rates of bed movement, apart from variable amounts of supplied air, also affected significantly the generated zone heights and syngas composition. Fast bed movement in the gasifier (Case 2) promoted pyrolysis process with the height of the zone (Figure 3), which led to a slightly reduced production of pyrolytic gas and higher calorific value of the syngas (Table 3 ). In Case 1, slow movement of fixed bed resulted in the formation of a high zone of oxidation and reduction (Figure 2) that influenced the lower content of carbon dioxide, hydrogen and methane and increased the amount of generated syngas.

Based on the literature, the amount of produced gas was calculated using the nitrogen tracer method (Chen et al., 2012; Thanapal, 2010), which relies on knowing the amount of nitrogen in the supplied air. The results revealed that the slow bed movement in the gasifier led to a larger gas yield per kg of biomass; the peak value was $1.6 \mathrm{Nm}^{3} / \mathrm{kg}_{\text {biomass }}$ for $23 \mathrm{Nm}^{3} / \mathrm{h}$ of supplied air. At fast bed movement in the gasifier, the corresponding value was $1.3 \mathrm{Nm}^{3} / \mathrm{kg}_{\text {biomass }}$. Furthermore, an increase in the amount of air supplied to the gasifier resulted in an increase in the amount of gas yield per $\mathrm{kg}$ of biomass for both cases, which is consistent with the literature (Chen et al., 2012; Ismail and El-Sala, 2017).

Specific gas energy $(\mathrm{MJ} / \mathrm{kg})$ is an additional parameter representing the amount of energy obtained from a kilogram per hour of solid fuel in the form of gaseous fuel (Taupe et al., 2016) and allows to determine the energy efficiency of the gasification process. For both Cases, experimental results showed that the specific gas energy reached similar value (Table 3). However, in Case 1 these values were reached at lower fuel consumption (Table 2). It is caused by lower heating values of produced gas $\left(4.8-6.2 \mathrm{MJ} / \mathrm{Nm}^{3}\right)$ with a

Table 3 Syngas composition

Tablica 3. Sastav sintetskog plina

\begin{tabular}{|c|c|c|c|c|c|c|c|c|c|}
\hline \multirow{2}{*}{$\begin{array}{c}\text { Case } \\
\text { Primjer }\end{array}$} & \multirow{2}{*}{$\begin{array}{c}\text { Air / Zrak } \\
\mathrm{Nm}^{3} / \mathrm{h}\end{array}$} & \multirow{2}{*}{$\begin{array}{l}\text { ER } \\
E R\end{array}$} & \multicolumn{4}{|c|}{$\begin{array}{l}\text { Syngas components, } \% \\
\text { Sastav sintetskog plina, \% }\end{array}$} & \multirow{2}{*}{$\begin{array}{c}\text { LHV of gas } \\
L H V \text { plina } \\
\mathrm{MJ} / \mathrm{Nm}^{3}\end{array}$} & \multirow{2}{*}{$\begin{array}{c}\text { Gas yield } \\
\text { Prinos plina } \\
\mathrm{Nm}^{3} / \mathrm{kg}_{\text {biomase }}\end{array}$} & \multirow{2}{*}{$\begin{array}{c}\text { Specific energy } \\
\text { Specifična energija } \\
\mathrm{MJ} / \mathrm{kg}\end{array}$} \\
\hline & & & $\mathrm{CO}$ & $\mathrm{CO}_{2}$ & $\mathrm{H}_{2}$ & $\mathrm{CH}_{4}$ & & & \\
\hline \multirow{4}{*}{$\begin{array}{c}\text { Case } 1 \\
\text { primjer } 1 .\end{array}$} & 12 & 0.16 & 25.3 & 5.6 & 6.9 & 2.4 & 4.8 & 1.4 & 6.72 \\
\hline & 17 & 0.16 & 33.8 & 4.8 & 8.2 & 1.8 & 5.8 & 1.5 & 8.70 \\
\hline & 20 & 0.16 & 32.2 & 5.7 & 8.4 & 1.3 & 5.5 & 1.6 & 8.80 \\
\hline & 23 & 0.16 & 35.5 & 4.4 & 8.5 & 2.1 & 6.2 & 1.6 & 9.92 \\
\hline \multirow{4}{*}{$\begin{array}{c}\text { Case } 2 \\
\text { primjer } 2 .\end{array}$} & 12 & 0.09 & 34.6 & 9.6 & 14.4 & 3.9 & 7.3 & 1.0 & 7.30 \\
\hline & 17 & 0.12 & 33.4 & 7.1 & 12.1 & 3.1 & 6.7 & 1.2 & 8.04 \\
\hline & 20 & 0.13 & 33.3 & 8.3 & 11.3 & 2.7 & 6.4 & 1.4 & 8.96 \\
\hline & 23 & 0.13 & 36.8 & 7.5 & 11.5 & 2.6 & 6.8 & 1.3 & 8.84 \\
\hline
\end{tabular}




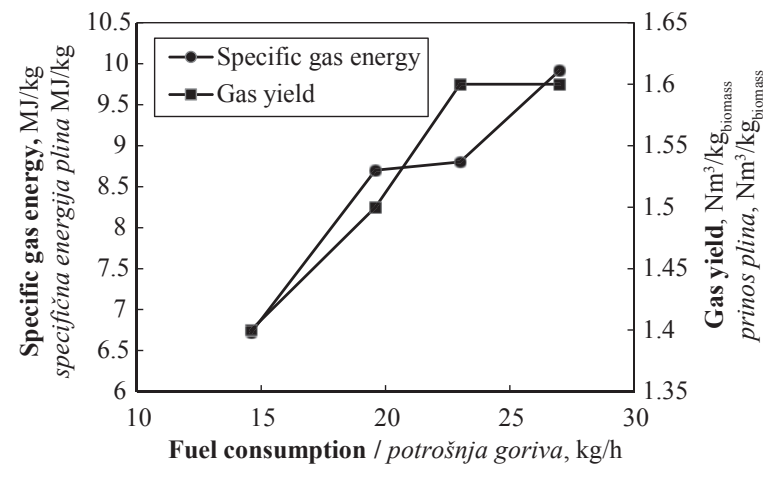

Figure 4 Relation of fuel consumption and specific gas energy and gas yield in Case 1

Slika 4. Odnos potrošnje goriva i specifične energije plina te prinosa plina u primjeru 1 .

higher gas yield (1.4 - $\left.1.6 \mathrm{Nm}^{3} / \mathrm{kg}_{\text {biomass }}\right)$ in Case 1 , and accordingly higher heating values of produced gas (6.4-7.3 MJ/ $\left.\mathrm{Nm}^{3}\right)$ with a lower gas yield $\left(1.0-1.4 \mathrm{Nm}^{3} /\right.$ $\mathrm{kg}_{\text {biomass }}$ ) in Case 2. Moreover, the results showed that, for the slow fuel motion in the reactor (Case 1), the gasification process reached the maximum gas yield with a fuel consumption of $23 \mathrm{~kg} / \mathrm{h}(\mathrm{ER}=0.21)$ (Figure 4). In Case 2 (Figure 5) maximum gas yield was reached with a fuel consumption of $28.8 \mathrm{~kg} / \mathrm{h}$. This aspect indicates the potentially optimal process conditions for the presented Cases (char outlet velocity).

\subsection{Char characteristic}

3.4. Svojstva pougljenjenog materijala

Experimental investigations of hardwood pellet gasification revealed the impact of stimulated bed movement in the reactor on fuel consumption (Table 4). As the amount of supplied air increased from 12 to $23 \mathrm{Nm}^{3} / \mathrm{h}$, the fuel consumption increased from 14.6 $\mathrm{kg} / \mathrm{h}$ to $27 \mathrm{~kg} / \mathrm{h}$ in Case 1 and from $26.2 \mathrm{~kg} / \mathrm{h}$ to 33.7 $\mathrm{kg} / \mathrm{h}$ in Case 2. This relation was also presented by Pedroso et al. (2013), who showed that the increase in the amount of air from 21 to $28 \mathrm{Nm}^{3} / \mathrm{h}$ caused an increase in fuel consumption from 10 to $14 \mathrm{~kg} / \mathrm{h}$ during updraft gasification of woodchips. Furthermore, a larger amount of oxygen supplied to the gasifier intensified the oxidization reaction, which led to an increase in the carbon conversion rate. In Case 1, an increase in the amount of supplied air from 12 to $23 \mathrm{Nm}^{3} / \mathrm{h}$ resulted in increased carbon conversion from 70 to $94 \%$. In Case

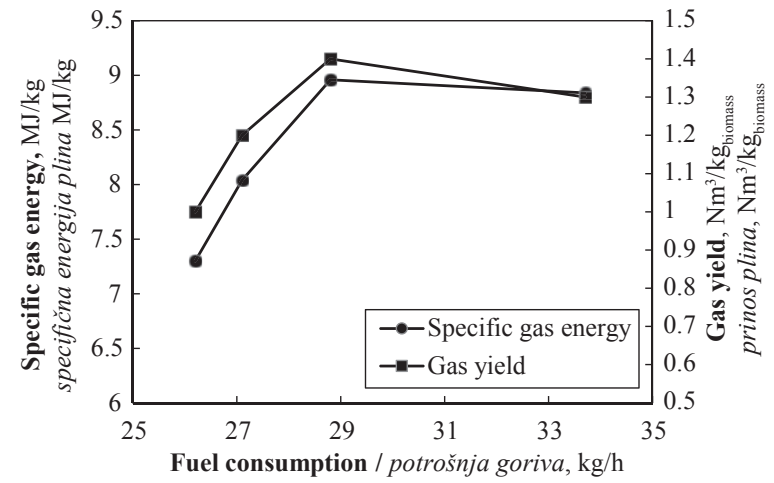

Figure 5 Relation of fuel consumption and specific gas energy and gas yield in Case 2

Slika 5. Odnos potrošnje goriva i specifične energije plina te prinosa plina u primjeru 2 .

2, the corresponding data were 78 and $83 \%$, respectively. A larger amount of oxygen supplied to the gasifier promoted oxidization reactions and led to increased $\mathrm{CO}_{2}$ generation. These aspects were presented by Kalström et al. (2015). These authors found that an increase in carbon dioxide concentration from 13 to $60 \%$ significantly affected the char conversion rate during $\mathrm{CO}_{2}$ gasification of char particles from torrefied fuels like pine shell, olive stones and straw.

The carbon conversion was calculated as the ratio of the carbon difference in biomass and char after gasification compared with the amount of carbon in the biomass. The theoretical amount of char was based on the difference in the mass of carbon in the fuel and the resulting syngas. These calculations did not take into account the tars. The experimental results revealed that optimum conditions were achieved for fast movement of fixed bed in the gasifier (Case 2) for $20 \mathrm{Nm}^{3} / \mathrm{h}$, where the smallest difference between the received and calculated amount of produced char was obtained, which may indicate the high fuel conversion rate, lowest accumulation of carbon (char) in the reactor and low tar content.

\subsection{Mass and energy balance}

3.5. Masa i energetska bilanca

An important parameter for comparing the impact of the rate of bed movement in the gasifier and the amount of supplied air on the updraft gasification process is a mass and energy balance. The energy input

Table 4 Performance data of gasification process

Tablica 4. Podatci o procesu rasplinjavanja

\begin{tabular}{|l|c|c|c|c|c|c|c|c|c|}
\hline & \multicolumn{3}{|c|}{ Case 1/ Primjer 1. } & \multicolumn{5}{c|}{ Case 2 / Primjer 2. } \\
\hline Amount of supplied air / Količina dobave zraka & $\mathrm{Nm}^{3} / \mathrm{h}$ & 12 & 17 & 20 & 23 & 12 & 17 & 20 & 23 \\
\hline Fuel consumption / Potrošnja goriva & $\mathrm{kg} / \mathrm{h}$ & 14.6 & 19.6 & 23.0 & 27.0 & 26.2 & 27.1 & 28.8 & 33.7 \\
\hline Carbon in the fuel / Ugljik u gorivu & $\mathrm{kg} / \mathrm{h}$ & 7.1 & 9.5 & 11.2 & 13.1 & 12.7 & 13.1 & 13.9 & 16.4 \\
\hline Char received / Količina pougljenjenog materijala & $\mathrm{kg} / \mathrm{h}$ & 2.6 & 1.1 & 0.8 & 0.8 & 3.4 & 3.2 & 3.5 & 2.9 \\
\hline $\begin{array}{l}\text { Carbon content in the char / Sadržaj ugljika u } \\
\text { pougljenjenome materijalu }\end{array}$ & $\%$ & 84.0 & 87.4 & 97.5 & 97.8 & 82.3 & 87.3 & 92.8 & 96.8 \\
\hline Carbon conversion / Pretvorba ugljika & $\%$ & 70 & 91 & 93 & 94 & 78 & 79 & 76 & 83 \\
\hline Mass of carbon in the gas / Masa ugljika u plinu & $\mathrm{kg} / \mathrm{h}$ & 3.5 & 6.2 & 8.1 & 9.5 & 6.5 & 7.2 & 9.1 & 10.3 \\
\hline $\begin{array}{l}\text { Theoretical char / Teorijska količina pougljenjenog } \\
\text { materijala }\end{array}$ & $\mathrm{kg} / \mathrm{h}$ & 4.2 & 3.8 & 3.2 & 3.6 & 7.9 & 6.8 & 5.2 & 7.5 \\
\hline
\end{tabular}




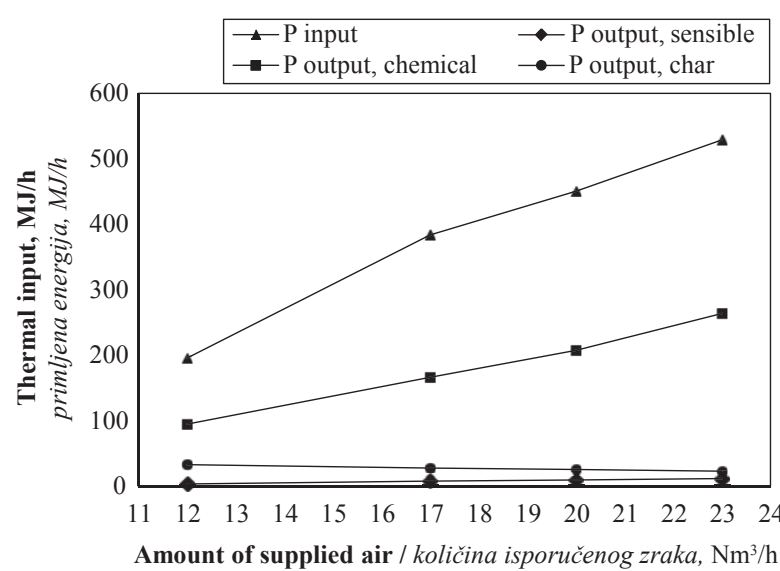

Figure 6 Characteristics of input and output energy during updraft gasification in Case 1

Slika 6. Obilježja primljene i otpuštene energije tijekom protusmjernog rasplinjavanja u primjeru 1 .

flow was defined as the product of fuel consumption per unit time (Table 4) and the higher heating value of hardwood pellets (Table 1):

$$
P_{\text {input }}=\dot{m}_{\text {fuel }} \cdot H H V_{\text {fuel }}(M J / h)
$$

The energy output flow associated with chemical energy in the syngas was calculated from the volumetric composition of the combustible species contained in the syngas and their caloric value (Table 2):

$$
P_{\text {out }, \text { chemical }}=\sum_{i} V_{i} \cdot H H V_{i}(M J / h)
$$

The syngas produced at the outlet of the reactor was very hot and also carried a certain amount of heat (sensible heat), which can be defined as a product of the specific heat capacity, the molar flow of each component and the outlet temperature of the syngas:

$$
P_{\text {out }, \text { sensible }}=\sum_{i} \dot{n}_{i} \int_{T_{\text {anbient }}}^{T_{\text {gas oultet }}} c_{p, i} d T(M J / h)
$$

The specific heat capacity $c_{p, i}$ at different temperatures is well known in the literature (Nederlandse Gasunie, 1988), and the molar flow of each component was calculated from the data given in Table 4 . The syngas temperature at the outlet of the gasifier was no more than $230^{\circ} \mathrm{C}$.

A certain amount of char was collected during gasification of hardwood pellets in each experimental series (from 0.8 to $3.5 \mathrm{~kg} / \mathrm{h}$; Table 4 ). For this reason, the energy output contained in the char $P_{\text {out,char }}$ was also taken into account and was defined as the product of char received per unit time (Table 3) and its higher heating value:

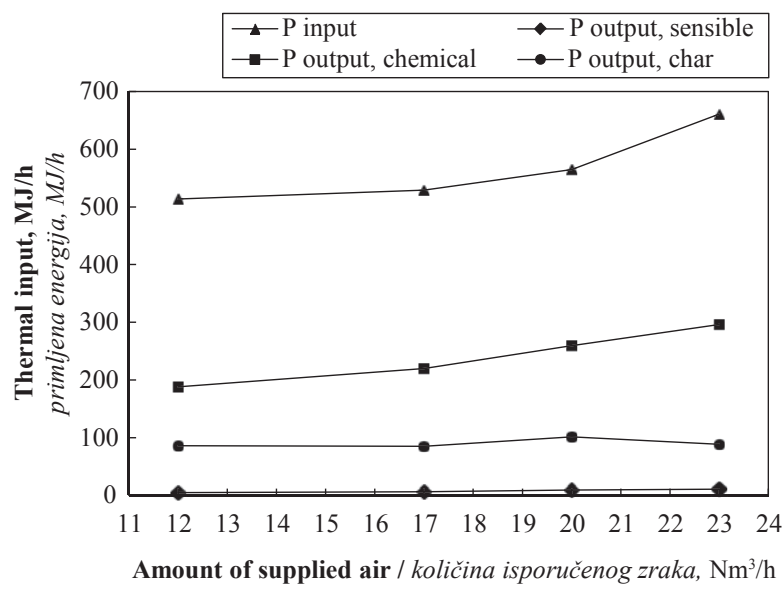

Figure 7 Characteristics of input and output energy during updraft gasification in Case 2

Slika 7. Svojstva primljene i otpuštene energije tijekom protusmjernog rasplinjavanja u primjeru 2 .

$$
P_{\text {out }, \text { char }}=\dot{m}_{\text {char }} \cdot H H V_{\text {char }}(M J / h)
$$

Our experimental results revealed that the energy input contained in the hardwood pellets reached, at 23 $\mathrm{Nm}^{3} / \mathrm{h}$ of supplied air, $530 \mathrm{MJ} / \mathrm{h}$ in Case 1 and 660 $\mathrm{MJ} / \mathrm{h}$ in Case 2 (Table 4). For both cases, the largest fraction of the calculated output energy was chemical energy in the syngas (Figure 4 and Figure 5), from 94 $\mathrm{MJ} / \mathrm{h}$ (at $12 \mathrm{Nm}^{3} / \mathrm{h}$ of supplied air) to $530 \mathrm{MJ} / \mathrm{h}$ (at 23 $\mathrm{Nm}^{3} / \mathrm{h}$ of supplied air) in Case 1 (Figure 4) and from 513 to $660 \mathrm{MJ} / \mathrm{h}$, respectively, in Case 2. The higher output energy in Case 2 is associated with the promotion of the pyrolysis process and the production of syngas with a higher calorific value.

The analysis of heat input and output during updraft gasification of hardwood pellets revealed a deviation of 33-47 \% in the heat balance (Table 5), which might be caused by our not taking into account the energy output of tars and the heat loss of the installation.

According to the findings of Ayyadurai et al. (2017), it is difficult to heat balance the gasification process. These authors showed that the deviation in the heat balance reached $22 \%$. They also found that the chemical energy contained in the syngas represented nearly $60 \%$ of the output energy. In our study, the work chemical energy was balanced from $57-88 \%$ in Case 1 and from $67-74 \%$ in Case 2.

The char was gathered from the bottom of the reactor using an inverter coupled with a cyclical screw at a frequency of $5 \mathrm{sec} / 5 \mathrm{~min}$ (Case 1) and 10 $\mathrm{sec} / 2.5 \mathrm{~min}$ (Case 2), which stimulated bed movement in the reactor.

Table 5 Energy balance

Tablica 5. Energetska bilanca

\begin{tabular}{|l|c|c|c|c|c|c|c|c|c|}
\hline & & \multicolumn{4}{|c|}{ Case 1/Primjer 1. } & \multicolumn{4}{c|}{ Case 2 / Primjer 2.} \\
\hline Amount of supplied air / Količina dobave zraka & $\mathrm{Nm} / \mathrm{h}$ & 12 & 17 & 20 & 23 & 12 & 17 & 20 & 23 \\
\hline Fuel consumption / Potrošnja goriva & $\mathrm{kg} / \mathrm{h}$ & 14.6 & 19.6 & 23.0 & 27.0 & 26.2 & 27.1 & 28.8 & 33.7 \\
\hline Thermal input / Toplinski ulaz & $\mathrm{MJ} / \mathrm{h}$ & 196 & 384 & 450 & 529 & 513 & 529 & 564 & 660 \\
\hline Thermal output / Toplinski izlaz & $\mathrm{MJ} / \mathrm{h}$ & 168 & 205 & 246 & 303 & 284 & 316 & 375 & 401 \\
\hline Deviation / Odstupanje & $\%$ & 15 & 47 & 45 & 43 & 45 & 40 & 33 & 39 \\
\hline
\end{tabular}


Table 6 Energy characteristics of char

Tablica 6. Energetska obilježja pougljenjenog materijala

\begin{tabular}{|l|c|c|c|c|c|c|c|c|}
\hline & \multicolumn{3}{|c|}{ Case 1/ Primjer 1. } & \multicolumn{4}{c|}{ Case 2 / Primjer 2.} \\
\hline Air / Zrak, $\mathrm{Nm}^{3} / \mathrm{h}$ & 12 & 17 & 20 & 23 & 12 & 17 & 20 & 23 \\
\hline Fuel consumption / Potrošnja goriva, $\mathrm{kg} / \mathrm{h}$ & 14.6 & 19.6 & 23.0 & 27.0 & 26.2 & 27.1 & 28.8 & 33.7 \\
\hline Char received / Količina pougljenjenog materijala, $\mathrm{kg} / \mathrm{h}$ & 2.6 & 1.1 & 0.8 & 0.8 & 3.4 & 3.2 & 3.5 & 2.9 \\
\hline $\begin{array}{l}\text { Carbon content in char/Sadržaj ugljika u pougljenjenome } \\
\text { materijalu, \% }\end{array}$ & 84.0 & 87.4 & 97.5 & 97.8 & 82.3 & 87.3 & 92.8 & 96 \\
\hline $\mathrm{P}_{\text {out,char }}, \mathrm{MJ} / \mathrm{kg}$ & 32.81 & 27.63 & 25.39 & 23.04 & 86.51 & 85.28 & 101.83 & 88.52 \\
\hline
\end{tabular}

The energy output contained in the char $\mathrm{P}_{\text {out }}$ is also an important part of the output energy. As shown in Table 6, in Case 2, the thermal output reached 100 $\mathrm{MJ} / \mathrm{h}$ with a fuel consumption of $28.8 \mathrm{~kg} / \mathrm{h}(20 \mathrm{Nm} 3 / \mathrm{h}$ of air) and remained at a similar level $(85 \mathrm{MJ} / \mathrm{h})$ for the other cases. An increase in air supplied to the gasifier for the slow movement of the bed (Case 1) caused a decrease in the quantity of received char (from 2.6 to $0.8 \mathrm{~kg} / \mathrm{h}$ ) and a decrease in the char output energy from 66 to $23 \mathrm{MJ} / \mathrm{h}$. This aspect shows that fast bed movement in the reactor, stimulated by char outlet velocity, leads to a high amount of the char with a high energy potential, which can react with steam and form clean energy gas.

Our experimental investigation revealed that sensible heat contained in the producer gas did not constitute a significant infraction of the output energy balance; the sensible heat reached $11 \mathrm{MJ} / \mathrm{h}$ in Case 1 and $10 \mathrm{MJ} / \mathrm{h}$ in Case 2 (Figure 4 and Figure 5).

\section{CONCLUSIONS}

\section{ZAKLJUČAK}

Updraft gasification of hardwood pellets with different bed movement in the reactor and for 12, 17, 20 and $23 \mathrm{Nm}^{3} / \mathrm{h}$ of supplied air has been developed and evaluated. The following conclusions were drawn:

1. The results indicated a significant effect of bed movement in the reactor suggesting that the gasifier could be considered as a flow reactor.

2. Slow bed movement promotes a higher combustion and reduction zone, which leads to syngas maximum calorific value of about $6 \mathrm{MJ} / \mathrm{Nm}^{3}$, while fast movement of the bed promotes a higher pyrolysis zone and generates more calorific gas $\left(6-7 \mathrm{MJ} / \mathrm{Nm}^{3}\right)$.

3. The results indicate that slow bed movement, in comparison to fast bed movement, generated a higher syngas yield, with its lower caloric value. These results showed that in both Cases similar specific energy values were obtained. However, lower fuel consumption was reached in Case 1.

4. Fast bed movement in the reactor leads to a high amount of generated char with high energy potential.

5. An energy balance analysis was carried out for all considered cases. The total calculated input energy flow attained a maximum of $560 \mathrm{MJ} / \mathrm{h}$ for slow bed movement and $660 \mathrm{MJ} / \mathrm{h}$ for fast bed movement (at $23 \mathrm{Nm}^{3} / \mathrm{h}$ of supplied air), and the output energy flow was 303 and $400 \mathrm{MJ} / \mathrm{h}$, respectively. The devia- tion of $30-40 \%$ in heat balance was caused by not taking into account the tars and heat losses. Furthermore, it was noted that the chemical energy in the syngas represented $60-80 \%$ of the output energy.

6. Both cases of updraft hardwood pellet gasification generated high-quality gas. However, based on the temperature characteristics, performance data, carbon conversion efficiency and energy balance analysis, it was found that the fast movement of the bed with $20 \mathrm{Nm}^{3} / \mathrm{h}$ of supplied air yielded the highestquality gasification process.

\section{REFERENCES}

\section{LITERATURA}

1. Arena, U., 2012: Process and technological aspects of municipal solid waste gasification. A review. Waste Manage, 32: 625-639.

https://doi.org/10.1016/j.wasman.2011.09.025.

2. Ayyadurai, S.; Schoenmakers, L.; Hernández, J. J., 2017: Mass and energy analysis of a $60 \mathrm{~kW}_{\text {th }}$ updraft gasifier using large size biomass. Fuel, 187: 356-366. https://doi.org/10.1016/j.fuel.2007.03.028.

3. Balu, E., Chung, N., 2012: System characteristics and performance evaluation of a trailer - scale downdraft gasifier with different feedstock. Bioresource Technol, 108: 264-273.

https://doi.org/10.1016/j.biortech.2011.12.105.

4. Blasi, D. C.; Signorelli, G.; Portoricco, G., 1999: Countercurrent Fixed-Bed Gasification of Biomass at Laboratory Scale. Ind. Eng. Chem. Res., 38: 2571-2581. https:// doi.org/10.1021/ie980753i.

5. Chen, W.; Annamalai, K.; Ansley, R. J.; Mirik, M., 2012: Updraft fixed bed gasification of mesquite and juniper wood samples. Energy, 41: 454-461. https://doi.org/10.1016/j.energy.2012.02.052.

6. Dudyński, M.; Kwiatkowski, K.; Bajer, K., 2012: From feathers to syngas - Technologies and devices. Waste Manage, 32: 685-691.

https://doi.org/10.1016/j.wasman.2011.11.017.

7. Erlich, C.; Fransson, T. H., 2011: Downdraft gasification of pellets made of wood, palm-oil residues respective bagasse: Experimental study. Applied Energy, 88: 899-908. https://doi.org/10.1016/j.apenergy.2010.08.028.

8. Huang, S.; Wu, S.; Wu, Y.; Gao, J., 2017: Structure characteristics and gasification activity of residual carbon from updraft fixed-bed biomass gasification ash. Energy Conversation and Management, 36: 108-118. https://doi.org/10.1016/j.enconman.2016.12.091.

9. Ismail, T. M., El-Sala, M. A., 2017: Parametric studies on biomass gasification process on updraft gasifier high temperature air gasification. Applied Thermal Engineering, 112: 1460-1473.

https://doi.org/10.1016/j.applthermaleng.2016.10.026. 
10. Joseph, H.; Kihedu, J. H.; Yoshiie, R.; Naruse, I., 2016: Performance indicators for air and air-steam auto-thermal updraft gasification of biomass in packed bed reactor. Fuel Processing Technology, 141: 93-98. https://doi.org/10.1016/j.fuproc.2015.07.015.

11. Karlström, O.; Costa, M.; Brink, B.; Hupa, M., 2015: $\mathrm{CO}_{2}$ gasification rates of char particles from torrefied pine shell. Fuel, 158: 753-763. https://doi.org/10.1016/j.fuel.2015.06.011.

12. Mani, T.; Mahinpey, N.; Murugan, M., 2011: Reaction kinetics and mass transfer studies of biomass char gasification with $\mathrm{CO}_{2}$. Chemical Engineering Science, 66: 3641. https://doi.org/10.1016/j.ces.2010.09.033.

13. McKendry, P., 2002: Energy production from biomass (part 3): gasification technologies. Bioresource Technology, 83: 55-63. https://doi.org/10.1016/S0960-8524(01)00120-1.

14. Nederlandse Gasunie, N. V., 1988: Physical properties of natural gases.

15. Nisamaneenate, J.; Aton, D.; Sornkade, P.; Sricharoenchaikul, V., 2012: Fuel gas production from peanut shell waste using a modular downdraft gasifier with the thermal integrated unit. Renewable Energy, 79: 45-50. https://doi.org/10.1016/j.renene.2014.09.046.

16. Pedroso, D. T.; Machín, E. B.; Silveira, J. S.; Nemoto, Y., 2013: Experimental study of bottom feed updraft gasifier. Renewable Energy, 57: 311-316. https://doi.org/10.1016/j.renene.2013.01.056.

17. Phuphuakrat, T.; Nipattummakul, N.; Namioka, T.; Kerdsuwan, S.; Yoshikawa, K., 2010: Characterization of tar content in the syngas produced in a downdraft type fixed bed gasification system from dried sewage sludge. Fuel, 89: 2278-2284.

https://doi.org/10.1016/j.fuel.2010.01.015.
18. Sircar, I.; Sane, A.; Wang, W.; Gore, J. P., 2014: Experimental and modeling study of pinewood char gasification with $\mathrm{CO}_{2}$. Fuel, 119: 38-46. https://doi.org/10.1016/j. fuel.2013.11.026.

19. Taupe, N. C.; Lynch, D.; Wnetrzak, R.; Kwapinska, M.; Kwapinski, W.; Leahy, J. J., 2016: Updraft gasification of poultry litter at farm-scale - A case study. Waste Management, 50: 324-333. https://doi.org/10.1016/j.wasman.2016.02.036.

20. Thanapal, S. S., 2010: Gasification of low ash partially composted dairy biomass with enriched air mixture. Master's thesis. Texas A\&M University.

21. Ueki, Y.; Torigoe, T.; Ono, H.; Yoshiie, R.; Kihedu, J. H.; Naruse, N., 2011: Gasification characteristics of woody biomass in the packed bed reactor. Proceedings of the Combustion Institute, 33: 1795-1800. https://doi.org/10.1016/j.proci.2010.07.080.

22. Zainal, Z. A.; Rifau, A.; Quadir, G. A.; Seetharamu, K. N., 2002: Experimental investigation of a downdraft biomass gasifier. Biomass and Bioenergy, 23: 283-289. https://doi.org/10.1016/S0961-9534(02)00059-4.

\section{Corresponding address:}

\section{JACEK KLUSKA}

Institute of Fluid Flow Machinery

Fiszera 14

80-231 Gdańsk, POLAND

e-mail: jkluska@imp.gda.pl 